University of Nebraska - Lincoln

DigitalCommons@University of Nebraska - Lincoln

Publications from USDA-ARS / UNL Faculty

U.S. Department of Agriculture: Agricultural

Research Service, Lincoln, Nebraska

2013

Greenhouse gas fluxes from no-till rotated corn in the upper

midwest

R. Michael Lehman

USDA-ARS, michael.lehman@ars.usda.gov

Shannon L. Osborne

USDA-ARS

Follow this and additional works at: https://digitalcommons.unl.edu/usdaarsfacpub

Lehman, R. Michael and Osborne, Shannon L., "Greenhouse gas fluxes from no-till rotated corn in the upper midwest" (2013). Publications from USDA-ARS / UNL Faculty. 1162.

https://digitalcommons.unl.edu/usdaarsfacpub/1162

This Article is brought to you for free and open access by the U.S. Department of Agriculture: Agricultural Research Service, Lincoln, Nebraska at DigitalCommons@University of Nebraska - Lincoln. It has been accepted for inclusion in Publications from USDA-ARS / UNL Faculty by an authorized administrator of DigitalCommons@University of Nebraska - Lincoln. 


\title{
Greenhouse gas fluxes from no-till rotated corn in the upper midwest ${ }^{\text {th }}$
}

\author{
R. Michael Lehman*, Shannon L. Osborne \\ USDA-ARS-North Central Agricultural Research Laboratory, Brookings, SD 57006, United States
}

\section{A R T I C L E I N F O}

\section{Article history:}

Received 24 September 2012

Received in revised form 27 February 2013

Accepted 28 February 2013

\section{Keywords:}

Dryland

Maize

GRACEnet

Methane

Nitrous oxide

No-till

\begin{abstract}
A B S T R A C T
We determined soil surface fluxes of greenhouse gases (carbon dioxide, nitrous oxide, methane) from no-till, dryland corn (Zea mays L.) in eastern South Dakota and tested the effect of rotation on greenhouse gas fluxes from corn. The corn was grown within a randomized, complete block study that included both a 2-year (corn-soybean) rotation and a 4-year (corn-field peas-winter wheat-soybean) rotation with plots containing the corn phase present in every year, 2007-2010. Annual carbon dioxide $\left(\mathrm{CO}_{2}\right)$ fluxes were between 1500 and $4000 \mathrm{~kg} \mathrm{CO}_{2}-\mathrm{Cha}^{-1}$ during the four-year study. Annual nitrous oxide $\left(\mathrm{N}_{2} \mathrm{O}\right)$ fluxes ranged from 0.8 to $1.5 \mathrm{~kg} \mathrm{~N}_{2} \mathrm{O}-\mathrm{N} \mathrm{ha}^{-1}$ with peak fluxes during spring thaw and following fertilization. Net methane $\left(\mathrm{CH}_{4}\right)$ fluxes in 2007 were close to zero, while fluxes for 2008-2010 were between 0.9 and $1.6 \mathrm{~kg} \mathrm{CH}_{4}-\mathrm{Cha}^{-1}$. Methane fluxes increased with consistently escalating values of soil moisture over the four-year period demonstrating that soils which previously exhibited neutral or negative $\mathrm{CH}_{4}$ flux may become net $\mathrm{CH}_{4}$ producers in response to multiyear climatic trends. No significant differences in gas fluxes from corn due to treatment (2-year vs. 4-year rotation) were observed. Mean net annual soil surface gas fluxes from corn calculated over four years for both treatments were $2.4 \mathrm{MgCO}_{2}-\mathrm{Cha}^{-1}$, $1.2 \mathrm{~kg} \mathrm{~N}_{2} \mathrm{O}-\mathrm{Nha}^{-1}$, and $0.9 \mathrm{~kg} \mathrm{CH}_{4}-\mathrm{Cha}^{-1}$. Annual global warming potentials (GWP) as $\mathrm{CO}_{2}$ equivalents were $572 \mathrm{~kg} \mathrm{ha}^{-1}$ and $30 \mathrm{~kg} \mathrm{ha}^{-1}$ for $\mathrm{N}_{2} \mathrm{O}$ and $\mathrm{CH}_{4}$, respectively. Measurements of soil carbon showed that the 4-yr rotation accrued $596 \mathrm{~kg} \mathrm{Cha}^{-1} \mathrm{yr}^{-1}$ in the top $30 \mathrm{~cm}$ of soil which would be more than sufficient (2.19 $\mathrm{Mg} \mathrm{CO}_{2} \mathrm{eq} \mathrm{ha}^{-1} \mathrm{yr}^{-1}$ ) to offset the annual GWP of the nitrous and methane emissions from corn. In contrast, the 2-year rotation lost $120 \mathrm{kgC} \mathrm{ha}^{-1} \mathrm{yr}^{-1}$ from the top $30 \mathrm{~cm}$ of soil resulting in corn being a net producer of greenhouse gases and associated GWP.
\end{abstract}

Published by Elsevier B.V.

\section{Introduction}

Predictive modeling of the magnitude and direction of global climate change depends on accurate estimates of elemental pools and fluxes that contribute to atmospheric composition (IPCC, 2007a). Dependable elemental pool and flux estimates must be founded on and validated by direct measurement of these quantities at relevant regional scales that include soil-climatic conditions and land use patterns that are globally significant (Adams et al., 2003). In 2002, the U.S. Department of Agriculture-Agricultural Research Service (ARS) established a national program of spatially-distributed sites that make direct measurements in agroecosystems of soil carbon

\footnotetext{
is Disclaimer: Mention of trade names or commercial products in this publication is solely for the purpose of providing specific information and does not imply recommendation or endorsement by the U.S. Department of Agriculture. USDA is an equal opportunity provider and employer.

* Corresponding author at: North Central Agricultural Research Laboratory, 2923 Medary Ave., Brookings, SD 57006, United States. Tel.: +1 605693 5205: fax: +1 6056935240 .

E-mail address: michael.lehman@ars.usda.gov (R.M. Lehman).
}

(C) pools and the fluxes of greenhouse gases (GHG) (carbon dioxide, $\mathrm{CO}_{2}$; nitrous oxide, $\mathrm{N}_{2} \mathrm{O}$; methane, $\mathrm{CH}_{4}$ ). The data generated by this program, the Greenhouse Gas Reduction through Carbon Enhancement Network (GRACEnet), are being deposited in a common database (publically accessible) to enable emission factor calculation, emission estimate validation, and predictive modeling (Jawson et al., 2005). Initial objectives of the GRACEnet program are to provide direct measurements of soil $\mathrm{C}$ pools and gas fluxes under a range of soil-climatic conditions that are associated with (i) regionally common agricultural practices; and, (ii) agricultural practices that may lead to enhanced $C$ sequestration and GHG mitigation.

Twelve percent of the world's terrestrial land surface is cropland (FAO, 2002); in the U.S., it is $18 \%$ or 179 million ha (Lubowski et al., 2006). Corn (Zea mays L.) is the number one crop in the U.S., occupying 46 million ha (NASS, 2012). The majority of corn is grown within the U.S. Corn Belt, a temperate region that stretches from eastern South Dakota to Ohio where corn is the dominant crop. Corn is a leader among commodity crops with its requirements for fertilizer inputs and production of plant biomass and therefore has a strong influence on $\mathrm{C}$ and nitrogen $(\mathrm{N})$ cycles. In many parts of the 
U.S. Corn Belt, corn is commonly raised in a 2-year corn-soybean (Glycine $\max (\mathrm{L}$.) Merr) rotation that takes advantage of reduced residue production, reduced pest pressure, and nitrogen additions to the soil by nitrogen fixing bacteria associated with the legume (Bullock, 1992; Carpenter-Boggs et al., 2000; Riedell et al., 2009). Alternatively, corn may be grown within a more diversified rotation that may provide greater nutrient and pest protection advantages (Bullock, 1992; Riedell et al., 2009). It is unclear if there are advantages with respect to GHG production from corn grown within a diversified rotation. In a three-year study of GHG emissions at a Minnesota location, Johnson et al. (2010) reported that $\mathrm{CO}_{2}$ and $\mathrm{N}_{2} \mathrm{O}$ fluxes were similar in corn grown within 2- and 4-year rotations. However, for methane, they found that corn grown in a 2-year rotation was a sink measuring about $1 \mathrm{~kg} \mathrm{CH}_{4}-\mathrm{Cha}^{-1}$ while corn grown in a 4-year rotation produced $0.4 \mathrm{~kg} \mathrm{CH}_{4}-\mathrm{Cha}^{-1}$. At an Indiana field site, rotated corn lowered $\mathrm{N}_{2} \mathrm{O}$ emissions $20 \%$ compared to continuous corn (Omonode et al., 2011).

A recent summary report on agricultural GHG specifically identified the lack of long-term field studies on GHG emission for the primary corn producing regions, especially for dryland systems (GGWP, 2010). We determined soil surface gas fluxes from no-till, dryland corn during the 2007-2010 growing seasons in eastern South Dakota and tested the effect of rotation on these fluxes by comparing corn grown within a 2-year (corn-soybean) rotation with corn grown in a 4-year (corn-field peas (Pisum sativum L.)-winter wheat (Triticum aestivum L.)-soybean) rotation. The study location in eastern South Dakota occupies the northwestern extent of the U.S. Corn Belt with Mollisol soils that are predominant within the Corn Belt.

\section{Materials and methods}

\subsection{Study site}

The 65 ha Eastern South Dakota Soil and Water Research Farm located in Brookings, South Dakota (44 $19^{\prime}$ N latitude; $96^{\circ} 46^{\prime} \mathrm{W}$ longitude) is operated by the North Central Agricultural Research Laboratory (USDA-ARS-Northern Plains Area) under a long-term lease agreement. The research farm is located at $500 \mathrm{~m}$ elevation in the Big Sioux Basin of the northern glaciated plains, a region with $58 \mathrm{~cm}$ mean annual precipitation (MAP) and a mean annual temperature (MAT) of $8^{\circ} \mathrm{C}$ (Bryce et al., 1998). This land is classified as Rolling Till Prairie within the Central Feed Grains and Livestock Region (NRCS, 2006). The physiographic region is the glaciated Missouri Plateau (USGS, 2003). The Mollisol soils are a Barnes sandy clay loam (fine-loamy, mixed, superactive, frigid Calcic Hapludoll) that are moderately drained, with a high total soil organic matter content (about $4 \%$ ), and a clay content of about $280 \mathrm{~g} \mathrm{~kg}^{-1}$ measured in the top $5 \mathrm{~cm}$ (Pikul et al., 2007).

\subsection{Experimental plots and agricultural management}

Corn was grown under no-till management within a randomized, complete block (4 replications) study that included a 2-year (corn-soybean) rotation and a 4-year (corn-field peas-winter wheat-soybean) rotation with replicate plots for each crop phase
Table 1

Initial soil characteristics by sampling depth.

\begin{tabular}{lcc}
\hline Property & \multicolumn{2}{l}{ Depth interval } \\
\cline { 2 - 3 } & $0-15 \mathrm{~cm}$ & $15-30 \mathrm{~cm}$ \\
\hline $\mathrm{pH}$ & 6.25 & 6.84 \\
Bulk density $\left(\mathrm{Mg} \mathrm{m}^{-3}\right)$ & 1.47 & 1.45 \\
Electrical conductivity $\left(\mu \mathrm{S} \mathrm{cm}^{-1}\right)$ & 166 & 220 \\
Nitrate $\left(\mathrm{mg} \mathrm{kg}^{-1}\right)$ & 17.46 & 4.67 \\
Total $\mathrm{N}\left(\mathrm{g} \mathrm{kg}^{-1}\right)$ & 1.54 & 1.05 \\
Total C $\left(\mathrm{g} \mathrm{kg}^{-1}\right)$ & 17.3 & 12.1 \\
\hline
\end{tabular}

present in every year, 2007-2010. The rainfed no-till plots $\left(93 \mathrm{~m}^{2}\right)$ were established in 2000 and basic soils characterization data were collected prior to crop planting (Table 1). Corn was planted in $0.5 \mathrm{~m}$ wide rows at $4.5 \mathrm{~cm}$ depth; hybrids, planting dates and densities are provided in Table 2. Starter fertilizer was applied at planting ( $90.75 \mathrm{~kg} \mathrm{ha}^{-1}$ total; banded, $5 \mathrm{~cm}$ below and $7.5 \mathrm{~cm}$ to the side of the seed furrow) that contained $15.68 \mathrm{~kg} \mathrm{ha}^{-1}, 17.63 \mathrm{~kg} \mathrm{ha}^{-1}$, and $11.98 \mathrm{~kg} \mathrm{ha}^{-1}$ of $\mathrm{N}, \mathrm{P}$, and $\mathrm{K}$ respectively. At the V6 growth stage (Table 2), the bulk of $\mathrm{N}$ (about $75 \%$ of annual application) was surface broadcast as 34-0-0 ammonium nitrate to reach a yield goal of $6095 \mathrm{~kg} \mathrm{ha}^{-1}$ (amount varied between 30 and $60 \mathrm{~kg} \mathrm{~N} \mathrm{ha}^{-1}$ depending on yearly soil analysis and residual soil nitrate). The only other $\mathrm{N}$ fertility in either rotation was starter $\mathrm{N}\left(16 \mathrm{~kg} \mathrm{~N} \mathrm{ha}^{-1}\right)$ applied at wheat planting with the seed in the 4-year rotation. Weeds were controlled with an annually-adjusted regime of 2, 4-D and glyphosate applications that were uniform across the test plots. Corn grain yield was estimated by harvesting $15 \mathrm{~m}$ of the center two rows from each experimental plot using a plot combine (Massey Ferguson, Haven, KS). Grain moisture and test weights were determined. Corn grain yield was adjusted to $155 \mathrm{~g} \mathrm{~kg}^{-1}$ moisture. Corn biomass was collected at maturity by hand sampling 12 random plants from each experimental plot; samples were dried for $120 \mathrm{~h}$ in a forced-air oven at $60^{\circ} \mathrm{C}$, and weighed to obtain dry weight.

\subsection{Soil sampling and analysis}

Composite cores $(3.2 \mathrm{~cm}$ diameter, $0-15$ and $15-30 \mathrm{~cm}$ depth intervals) were collected from the plots at every two years (2002-2010) following harvest and analyzed for $\mathrm{pH}$ (1:1 in water), EC, bulk density, total $\mathrm{N}$ and $\mathrm{C}$ by combustion (Nelson and Sommers, 1996). Soil samples were not pretreated to remove carbonates before dry combustion, but were tested for the presence of inorganic C (Nelson and Sommers, 1996) in samples having a $\mathrm{pH} \geq 7.0$. There was no inorganic $C$ detected at the $0-15$ and $15-30 \mathrm{~cm}$ sampling depths; therefore, measured total $\mathrm{C}$ is equivalent to organic C.

\subsection{Gas flux measurement}

We used vented PVC static flux chambers $(25 \mathrm{~cm}$ diameter $\times 15 \mathrm{~cm}$ height)(Hutchinson and Mosier, 1981) to measure GHG fluxes from the corn plots according to the guidance of Parkin and Venterea (2010). Two chambers per plot were temporarily installed (40 min) on PVC collars that were located between corn rows where there would be no wheel traffic during the growing season. Collars

Table 2

Planting; population hybrid utilized, fertilization date and rate and harvest dates.

\begin{tabular}{|c|c|c|c|c|c|c|}
\hline Year & Planting (mm/dd/yr) & Population (plants ha ${ }^{-1}$ ) & Hybrid & Fertilization $^{\mathrm{a}}(\mathrm{mm} / \mathrm{dd} / \mathrm{yr})$ & Applied in-season $\mathrm{N} \mathrm{kg} \mathrm{ha}^{-1}$ & Harvest (mm/dd/yr) \\
\hline 2007 & $4 / 30 / 07$ & 61,750 & Dekalb 42-22 & $6 / 08 / 07$ & 32 & $10 / 23 / 07$ \\
\hline 2008 & $5 / 15 / 08$ & 61,750 & Dekalb 42-22 & $6 / 23 / 08$ & 38 & $10 / 15 / 08$ \\
\hline 2009 & $5 / 04 / 09$ & 49,400 & Dekalb 38-89 & $6 / 18 / 09$ & 57 & $11 / 05 / 09$ \\
\hline 2010 & $5 / 18 / 10$ & 49,400 & Dekalb 38-89 & $6 / 17 / 10$ & 57 & $10 / 12 / 10$ \\
\hline
\end{tabular}

a Additionally, $16 \mathrm{~kg} \mathrm{~N} \mathrm{ha}^{-1}$ was banded at planting for all years. 
Table 3

Annual average temperature and precipitation totals ${ }^{\mathrm{a}}$

\begin{tabular}{lll}
\hline Year & $\begin{array}{l}\text { Average daily } \\
\text { temperature }\left({ }^{\circ} \mathrm{C}\right)\end{array}$ & $\begin{array}{l}\text { Annual accumulated } \\
\text { precipitation }(\mathrm{mm})\end{array}$ \\
\hline 2007 & 6.8 & 577 \\
2008 & 5.0 & 484 \\
2009 & 6.6 & 565 \\
2010 & 6.7 & 899 \\
$30-Y e a r$ average & 6.2 & 579 \\
\hline
\end{tabular}

a Data compiled on a calendar year basis from a weather station $300 \mathrm{~m}$ south of the research plots. The 30-year average data reported from the Brookings NWS/NOAA Coop weather station located five $\mathrm{km}$ southeast of the research plots.

were centered between rows which meant that banding of starter $\mathrm{N}$ fertilizer (about $25 \%$ of annual $\mathrm{N}$ application) occurred within $5 \mathrm{~cm}$ of each chamber. Collars were removed for planting and harvesting; a minimum of $24 \mathrm{~h}$ elapsed before resumption of sampling activities following collar installation. Sampling was scheduled for two-week intervals during the cropping season and monthly intervals during the remainder of the year. Sampling was discontinued during periods where installation of the chambers on the collars would have necessitated disturbance of snow cover. Each sampling session was centered on 10 a.m. and temperature data (air; soil, $5 \mathrm{~cm}$ depth; chamber) were collected with a thermometer for each block. Starting in Dec. 2007, soil moisture $(0-30 \mathrm{~cm})$ was measured at each chamber location immediately following each gas sampling event using time-domain reflectrometry (TDR) (Trase System model 6050X1, Soil Moisture Equipment Corp., Santa Barbara, CA). Prior to Dec. 2007, gravimetric soil moisture $(0-10 \mathrm{~cm})$ was measured on soil samples collected during three gas sampling occasions. Accompanying daily weather data (air temperature, precipitation) was collected by an automated weather station (CR10X, Campbell Scientific, Logan, UT) located $300 \mathrm{~m}$ south of the research plots. Local 30-year average temperature and total precipitation data were obtained from a National Weather Service Coop station located five $\mathrm{km}$ southeast of the research plots (Table 3 ).

At 20 min intervals, $10-\mathrm{ml}$ chamber headspace samples were collected with a syringe via a chamber septum and added to 10$\mathrm{ml}$, nitrogen-filled serum vials. All three gases $\left(\mathrm{CO}_{2}, \mathrm{~N}_{2} \mathrm{O}\right.$ and $\left.\mathrm{CH}_{4}\right)$ were quantified simultaneously by gas chromatography (Shimadzu 14B with a CombiPal AOC-5000 autosampler, 2-ml injection loop, Porapack Q precolumns, a 1/8" stainless steel Porapack Q (80/100 mesh) column, a Haysep-D column (columns operated at $60^{\circ} \mathrm{C}$ ), and a flame ionization detector and an electron capture detector both at $260^{\circ} \mathrm{C}$ ). Nitrogen was the carrier gas with air and hydrogen for the FID. All gases were of the highest grade and pre-filtered.
Calibration was routinely performed using dilutions of a certified, gas standard mix (Scott Specialty Gases, Plumsteadville, PA). Gas fluxes were calculated using linear regression and the average of two chambers used to represent each plot for further analysis.

For the purposes of calculating cumulative gas fluxes, the crop year was considered to be May 1 through April 30 of the following year. The fluxes on the first (May 1) and last (April 30) day of each crop year were assumed to be zero for $\mathrm{N}_{2} \mathrm{O}$ and $\mathrm{CH}_{4}$. For $\mathrm{CO}_{2}, 5000 \mathrm{~g} \mathrm{ha}^{-1} \mathrm{~d}^{-1}$ was used for the May 1 and April 30 dates to avoid underestimating the annual $\mathrm{CO}_{2}$ flux $\left(5620 \mathrm{~g} \mathrm{ha}^{-1} \mathrm{~d}^{-1}\right.$ was the calculated average for all April and May readings over the four years). Linear interpolation between measurements was the basis for integrated cumulative fluxes; negative fluxes were subtracted from positive fluxes to yield net cumulative fluxes. To express global warming potential (GWP), $\mathrm{N}_{2} \mathrm{O}$ and $\mathrm{CH}_{4}$ fluxes were converted to $\mathrm{CO}_{2}$ equivalents using 100-yr GWP factors for $\mathrm{N}_{2} \mathrm{O}$ (298) and $\mathrm{CH}_{4}$ (25) (IPCC, 2007b). For each gas, the main effects of the fixed treatment factor (rotation) on annual cumulative flux were tested for significance by analysis of variance procedures with block and year as the random factors. Pairwise comparisons between treatment-year combinations were tested for significant difference using Tukey's posthoc test.

\section{Results}

\subsection{Meteorological conditions, crop growth and soil carbon}

Average temperatures for the calendar years 2007, 2009, and 2010 were higher than the 30-yr average, while 2008 was cooler than average (Table 3). Annual precipitation in 2007 and 2009 was close to the 30 -yr average while 2008 was considerably drier and 2010 considerably wetter than the average. Overall grain yield for the experiment was below the regional average (Brookings County, SD: $7840 \mathrm{~kg} \mathrm{ha}^{-1}$ ) but was consistent with the $\mathrm{N}$ application for our experimental yield goal, except for the 2007 growing season which was below our yield goal (Table 4). Average monthly precipitation and temperature data compiled for the 2007-2010 growing seasons (Table 5) showed that rainfalls during the months of June and July of 2007 were less than half that of the following growing season (Table 5) and co-occurred with comparatively higher temperatures. The decreased grain yield (and $\mathrm{C}$ removed) in 2007 was not accompanied by a decrease in above-ground C, biomass production, C returned to the soil (Table 4). During the four years of GHG measurements there were no significant difference in grain yield, or above ground plant $\mathrm{C}$ components measured for the experiment due to differences in crop rotation length, except for total above-ground $C$ during 2009 which was significantly higher for the 4-year rotation compared to the 2-year rotation. Grain yield during the 2009 growing season was significantly higher than our experimental yield goal (Table 4). During this growing season environmental conditions exhibited mild temperatures with timely precipitation during June and July (Table 5).

Changes in soil $\mathrm{C}$ were calculated using fall-collected soil samples following one and two complete rotation cycles for the 4-year rotation treatment compared to the 2-year rotation (Table 6 ). Soil $\mathrm{C}$ values in the 4 -year rotation increased in the $0-15 \mathrm{~cm}$ depth interval compared to the 2 -year rotation which changed little,

Table 4

Mean corn yield, above ground carbon produced and grain carbon removed from the system, and the amount of plant carbon returned to the soil.

\begin{tabular}{|c|c|c|c|c|c|}
\hline Year & Rotation & $\begin{array}{l}\text { Corn yield } \\
\left(\mathrm{kg} \mathrm{ha}^{-1}\right)\end{array}$ & $\begin{array}{l}\text { Total above ground } \\
\mathrm{C}\left(\mathrm{kg} \mathrm{ha}^{-1}\right)\end{array}$ & $\begin{array}{l}\text { Corn } \mathrm{C} \text { removed } \\
\left(\mathrm{kg} \mathrm{ha}^{-1}\right)\end{array}$ & $\begin{array}{l}\text { Plant } C \text { returned } \\
\left(\mathrm{kg} \mathrm{ha}^{-1}\right)\end{array}$ \\
\hline \multirow[t]{4}{*}{2007} & \multirow[t]{2}{*}{$2 \mathrm{yr}$} & 4774 & 6049 & 2123 & 3926 \\
\hline & & $(823)^{a}$ & $(2144)$ & $(360)$ & (1997) \\
\hline & \multirow[t]{2}{*}{$4 \mathrm{yr}$} & 4253 & 5004 & 1880 & 3124 \\
\hline & & (867) & (1225) & (397) & (1475) \\
\hline \multirow[t]{4}{*}{2008} & \multirow[t]{2}{*}{$2 \mathrm{yr}$} & 5810 & 5579 & 2556 & 3022 \\
\hline & & (891) & (1513) & (395) & (1534) \\
\hline & \multirow[t]{2}{*}{$4 \mathrm{yr}$} & 6135 & 5989 & 2704 & 3285 \\
\hline & & $(888)$ & (1124) & $(400)$ & $(852)$ \\
\hline \multirow[t]{4}{*}{2009} & \multirow[t]{2}{*}{$2 \mathrm{yr}$} & 7966 & 5693 & 3539 & 2153 \\
\hline & & (545) & (613) & $(248)$ & (616) \\
\hline & \multirow[t]{2}{*}{$4 \mathrm{yr}$} & 8282 & 6228 & 3687 & 2541 \\
\hline & & (379) & $(892)$ & $(171)$ & (985) \\
\hline \multirow[t]{4}{*}{2010} & \multirow[t]{2}{*}{$2 \mathrm{yr}$} & 6786 & 5556 & 3026 & 2530 \\
\hline & & (683) & (143) & (314) & (337) \\
\hline & \multirow[t]{2}{*}{$4 \mathrm{yr}$} & 6499 & 6015 & 2884 & 3130 \\
\hline & & $(842)$ & (904) & $(366)$ & (938) \\
\hline
\end{tabular}

a Means \pm 1 standard error in parentheses. 
Table 5

Average monthly temperature and total monthly precipitation during active growing season, Brookings, SD 2007-2010.

\begin{tabular}{|c|c|c|c|c|}
\hline & 2007 & 2008 & 2009 & 2010 \\
\hline \multicolumn{5}{|c|}{ Average monthly temperature, ${ }^{\circ} \mathrm{C}$} \\
\hline June & 21.7 & 19.5 & 19.1 & 20.5 \\
\hline July & 23.9 & 23.1 & 20.2 & 23.6 \\
\hline Aug & 21.5 & 21.4 & 20.2 & 24.1 \\
\hline Sept & 17.6 & 16.9 & 17.9 & 15.7 \\
\hline \multicolumn{5}{|c|}{ Monthly precipitation totals, $\mathrm{mm}$} \\
\hline June & 72 & 141 & 90 & 217 \\
\hline July & 3 & 44 & 114 & 163 \\
\hline Aug & 147 & 28 & 42 & 122 \\
\hline Sept & 43 & 38 & 35 & 203 \\
\hline Total & 265 & 251 & 281 & 705 \\
\hline
\end{tabular}

\section{Table 6}

Changes in soil carbon by rotation and sampling depth following one and two complete rotational cycles for the 4-year rotation and corresponding changes in the 2-year rotation.

\begin{tabular}{lccr}
\hline \multirow{2}{*}{ Rotation } & Sampling & \multicolumn{2}{c}{ Delta carbon, $\mathrm{kgCha}^{-1}$} \\
\cline { 3 - 4 } & Depth, cm & $2002-2006^{\mathrm{a}}$ & $2006-2010$ \\
\hline $2 \mathrm{yr}$ & $0-15$ & $-149(933)$ & $204(1320)$ \\
& $15-30$ & $-34(1536)$ & $-685(835)$ \\
$4 \mathrm{yr}$ & $0-15$ & $1937(1051)$ & $1050(1036)$ \\
& $15-30$ & $1852(806)$ & $1332(1834)$ \\
\hline
\end{tabular}

a Means \pm 1 standard error in parentheses.

although the difference between the treatments was not statistically-significant. However, the 4-year rotation had a statistically-significant increase in soil C for the $15-30 \mathrm{~cm}$ sampling depth compared to the 2-year rotation which had a net loss of soil carbon in this depth interval. Combining the two depth intervals into a single $0-30 \mathrm{~cm}$ depth interval, the 2 -year rotation had an annual soil C $\operatorname{loss}\left(-120 \mathrm{~kg} \mathrm{Cha}^{-1}\right)$ and the 4-year rotation had a annual soil C gain ( $596 \mathrm{~kg} \mathrm{Cha}^{-1}$ ) over the $2006-2010$ time period. Measurements of annual changes in soil $\mathrm{C}$ were offset about six months from annual GHG flux measurements which were calculated starting May 1.

\subsection{Gas fluxes}

The annual patterns of accumulating net flux for $\mathrm{CO}_{2}$ (Fig. 1), $\mathrm{N}_{2} \mathrm{O}$ (Fig. 2), and $\mathrm{CH}_{4}$ (Fig. 3) were very similar for both rotational treatments in each year. Total annual net soil surface $\mathrm{CO}_{2}$ fluxes were between 1550 and $2650 \mathrm{~kg} \mathrm{CO}_{2}-\mathrm{Cha}^{-1}$ for three of the four years (Table 7). In 2007, which had the warmest, but driest, growing season (Fig. 4, Table 5), $\mathrm{CO}_{2}$ fluxes were between 3300 and $4000 \mathrm{~kg} \mathrm{CO}_{2}-\mathrm{Cha}^{-1}$. Nitrous oxide fluxes ranged from 0.8 to $1.5 \mathrm{~kg} \mathrm{~N}_{2} \mathrm{O}-\mathrm{N} \mathrm{ha}^{-1} \mathrm{yr}^{-1}$ with the lowest amount produced during 2007. Net methane fluxes in 2007 were nearly neutral, while estimates for 2008-2010 were between 0.9 and $1.6 \mathrm{~kg} \mathrm{CH}_{4}-\mathrm{Cha}^{-1} \mathrm{yr}^{-1}$. There was no significant effect of rotational treatment on the annual total fluxes of any of the three gases from corn (Table 8). There was a significant effect of year $(p<0.001)$ on $\mathrm{CO}_{2}$ flux and a significant interaction of year and rotation on $\mathrm{CO}_{2}$ flux $(p=0.007)$. Pairwise testing found that the $\mathrm{CO}_{2}$ flux from both treatments in 2007 was significantly higher than the other three years; and, that the $\mathrm{CO}_{2}$ flux from corn in the four-year rotation in 2008 was significantly lower than that in the two-year rotation in 2010 (Table 7). Coefficients of variation (CV) among replicate plots for net annual fluxes ranged from 3.6 to $28.4 \%$ for $\mathrm{CO}_{2}$, from 18.5 to $94.5 \%$ for $\mathrm{N}_{2} \mathrm{O}$, and 54.8 to $224.2 \%$ for $\mathrm{CH}_{4}$ (excluding the 2007 year for $\mathrm{CH}_{4}$ ).

Mean net annual gas fluxes calculated over four years for both treatments were $2.4 \mathrm{Mg} \mathrm{ha}^{-1}\left(\mathrm{CO}_{2}-\mathrm{C}\right), 1.2 \mathrm{~kg} \mathrm{ha}^{-1}\left(\mathrm{~N}_{2} \mathrm{O}-\mathrm{N}\right)$, and $0.9 \mathrm{~kg} \mathrm{ha}^{-1}\left(\mathrm{CH}_{4}-\mathrm{C}\right)$. The calculated
Table 8

Main effects testing of fluxes.

\begin{tabular}{lrll}
\hline Effect & $\mathrm{CO}_{2}{ }^{\mathrm{a}}$ & $\mathrm{N}_{2} \mathrm{O}$ & $\mathrm{CH}_{4}$ \\
\hline Rotation & 0.400 & 0.558 & 0.894 \\
Year & $<0.001$ & 0.521 & 0.239 \\
Rotation $\times$ year & 0.007 & 0.975 & 0.929 \\
\hline
\end{tabular}

a Probability of main effects.

annual GWP values for $\mathrm{N}_{2} \mathrm{O}$ and $\mathrm{CH}_{4}$ were $572 \mathrm{~kg} \mathrm{CO}_{2}$-eq ha ${ }^{-1}$ and $30 \mathrm{~kg} \mathrm{CO}_{2}$-eq ha ${ }^{-1}$, respectively.

Measured $\mathrm{CO}_{2}$ fluxes over the four years tracked seasonal temperature patterns, and fluxes commonly spiked following precipitation events (Fig. 4). Nitrous oxide fluxes exhibited peaks during spring thaw (March-April) and following in-season fertilization (June). Methane fluxes were variable, temporarily peaking after rainfall events, but also generally rising during the four year period which concluded with the wettest calendar year on record (2010) and widespread flooding in the upper Missouri River watershed in the spring of 2011. During this four-year period, soil moisture consistently increased from averages of $15 \%$ ( $\mathrm{vol} / \mathrm{vol}$ ) to greater than $35 \%$ (Fig. 5).

\section{Discussion}

\subsection{Carbon dioxide fluxes}

We found that mean annual soil surface fluxes of $\mathrm{CO}_{2}$ from dryland, no-till corn calculated over four years in this soil climatic region were $2.4 \mathrm{Mg} \mathrm{ha}^{-1}\left(\mathrm{CO}_{2}-\mathrm{C}\right)$ and that crop rotation did not have a significant effect on this flux. Johnson et al. (2010) also did not find significant differences in $\mathrm{CO}_{2}$ soil surface fluxes from corn grown within 2- and 4-year rotations in central Minnesota. Our annual soil surface flux was less than the three-year average $\mathrm{CO}_{2}$ flux of $3.7 \mathrm{Mg} \mathrm{CO}_{2}-\mathrm{Cha}^{-1} \mathrm{y}^{-1}$ from corn measured by Johnson et al. (2010) or the two-year average of $4.7 \mathrm{MgCO}_{2}-\mathrm{Cha}^{-1} \mathrm{y}^{-1}$ (Bavin et al., 2009) determined for a corn-soybean rotation in eastern Minnesota. Both of these Minnesota field trials were managed with tillage which could account for their higher $\mathrm{CO}_{2}$ fluxes. Alternatively, higher temperature and precipitation at the Minnesota sites or differences in the amount and form of $\mathrm{N}$ applied could account for differences in $\mathrm{CO}_{2}$ fluxes. $\mathrm{CO}_{2}$ emissions from a no-till wheat-fallow system in western Nebraska of $2.8 \mathrm{Mg} \mathrm{CO}_{2}-\mathrm{Cha}^{-1} \mathrm{y}^{-1}$ (Kessavalou et al., 1998) were similar in magnitude to our findings from notill corn. Annual patterns of $\mathrm{CO}_{2}$ closely tracked temperature with moisture driven peaks as observed by other researchers (Johnson et al., 2010; Liebig et al., 2010).

\subsection{Nitrous oxide fluxes}

Our mean annual flux of $\mathrm{N}_{2} \mathrm{O}$ from dryland, no-till corn in this soil climatic region was $1.2 \mathrm{~kg} \mathrm{ha}^{-1}\left(\mathrm{~N}_{2} \mathrm{O}-\mathrm{N}\right)$; there was no significant effect of rotation on the $\mathrm{N}_{2} \mathrm{O}$ flux from corn. Johnson et al. (2010) also found no difference due to rotation in $\mathrm{N}_{2} \mathrm{O}$ flux from tilled corn plots, but reported a $5 \mathrm{~kg} \mathrm{~N}_{2} \mathrm{O}-\mathrm{N} \mathrm{ha}^{-1} \mathrm{y}^{-1}$ average with consistent annual values over the three-year study. Omonode et al. (2011) also determined $\mathrm{N}_{2} \mathrm{O}$ emissions from corn that were around

Table 7

Statistical comparison of annual net gas fluxes from corn.

\begin{tabular}{|c|c|c|c|c|c|}
\hline Crop Year & Rotation & $\mathrm{CO}_{2}\left(\mathrm{Mg} \mathrm{ha}^{-1} \mathrm{yr}^{-1}\right)^{\mathrm{a}}$ & Statistical group ${ }^{\mathrm{b}}$ & $\mathrm{N}_{2} \mathrm{O}\left(\mathrm{kg} \mathrm{ha}^{-1} \mathrm{yr}^{-1}\right)$ & $\mathrm{CH}_{4}\left(\mathrm{~kg} \mathrm{ha}^{-1} \mathrm{yr}^{-1}\right)$ \\
\hline \multirow[t]{2}{*}{2007} & Four year & $3.91(0.07)$ & $\mathrm{a}$ & $0.866(0.163)$ & $0.078(0.336)$ \\
\hline & Two year & $3.31(0.22)$ & $\mathrm{a}$ & $0.817(0.092)$ & $-0.089(0.122)$ \\
\hline \multirow[t]{2}{*}{2008} & Four year & $1.56(0.22)$ & $\mathrm{b}$ & $1.13(0.388)$ & $0.870(0.967)$ \\
\hline & Two year & $1.85(0.12)$ & bc & $1.43(0.491)$ & $1.23(1.01)$ \\
\hline \multirow[t]{2}{*}{2009} & Four year & $1.91(0.05)$ & bc & $1.14(0.390)$ & $1.09(0.697)$ \\
\hline & Two year & $2.18(0.12)$ & $\mathrm{bc}$ & $1.36(0.642)$ & $1.17(0.828)$ \\
\hline \multirow[t]{2}{*}{2010} & Four year & $2.23(0.10)$ & bc & $1.33(0.123)$ & $1.60(0.439)$ \\
\hline & Two year & $2.63(0.16)$ & $\mathrm{cd}$ & $1.54(0.575)$ & $1.07(0.632)$ \\
\hline
\end{tabular}

\footnotetext{
a Means \pm 1 standard error in parentheses.
}

b Results of pairwise comparisons of net annual carbon dioxide flux among all rotation-year combinations; differing letters denote statistical differences. 

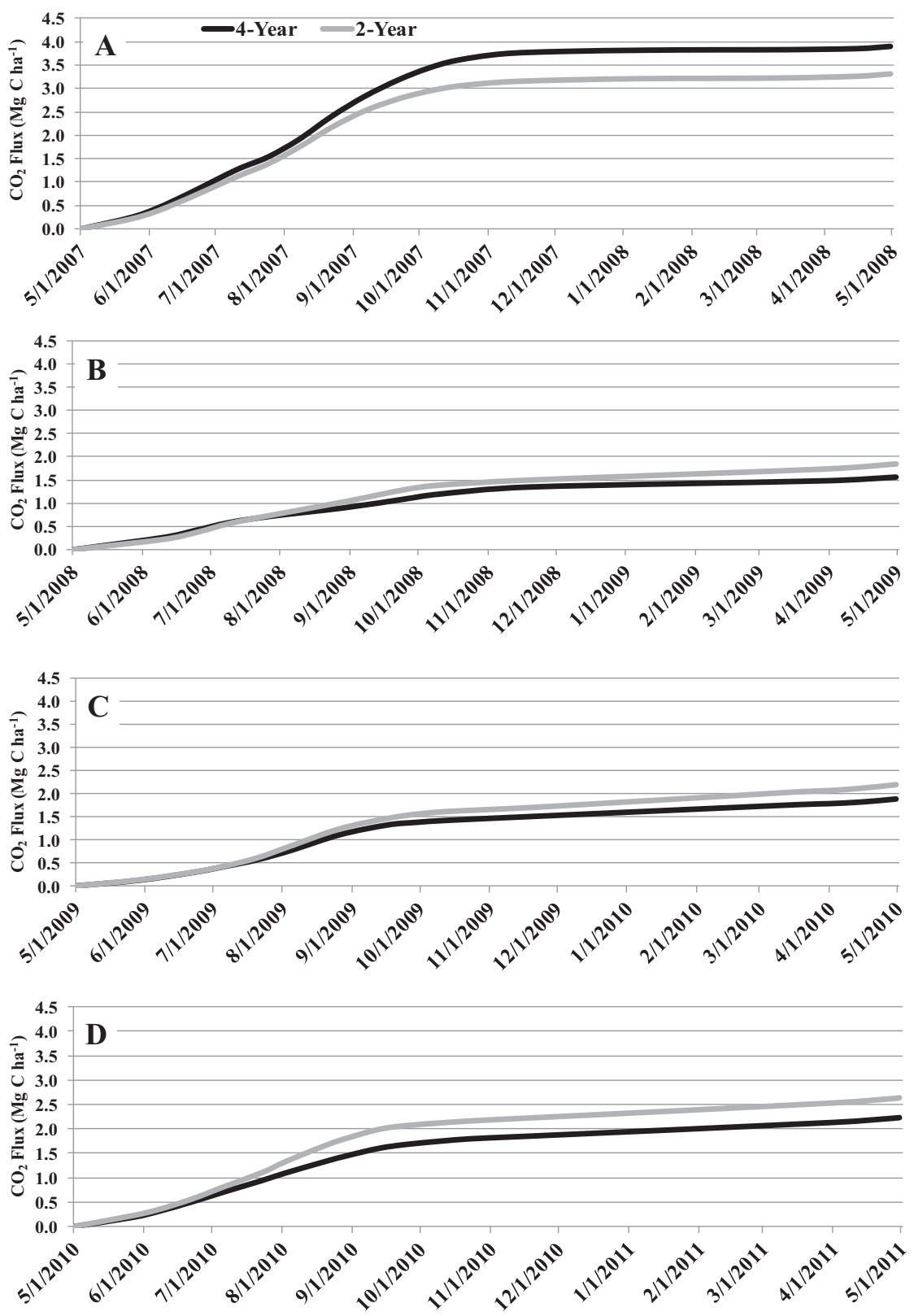

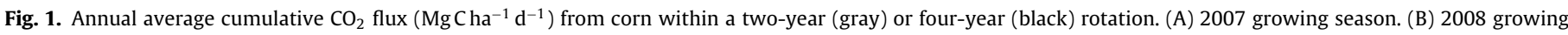
season. (C) 2009 growing season. (D) 2010 growing season.

$5 \mathrm{~kg} \mathrm{~N}_{2} \mathrm{O}-\mathrm{Nha}^{-1} \mathrm{y}^{-1}$, but fluxes were significantly higher in continuous corn compared to rotated corn in two of three years at an Indiana field site. Omonode et al. (2011) also found $\mathrm{N}_{2} \mathrm{O}$ fluxes were significantly lower in no-till systems compared to tilled systems in two of three years. Venterea et al. (2005) measured $\mathrm{N}_{2} \mathrm{O}$ emission of approximately $2.5 \mathrm{~kg} \mathrm{~N}_{2} \mathrm{O}-\mathrm{N} \mathrm{ha}^{-1} \mathrm{y}^{-1}$ from corn during 2003 in no-till plots from a Minnesota corn-soybean rotation using anhydrous ammonia as the $\mathrm{N}$ fertilizer with tilled plots' fluxes closer to $4 \mathrm{~kg} \mathrm{~N}_{2} \mathrm{O}-\mathrm{N} \mathrm{ha}^{-1} \mathrm{y}^{-1}$. Fluxes of $1-1.5 \mathrm{~kg} \mathrm{~N}_{2} \mathrm{O}-\mathrm{N} \mathrm{ha}^{-1} \mathrm{y}^{-1}$ were measured in 2003-2004 using urea ammonium nitrate or broadcast urea with tillage having little effect on flux (Venterea et al., 2005). In a study of $\mathrm{N}_{2} \mathrm{O}$ emissions from corn-soybean cropping systems in Iowa where regional yield averages are more than $8400 \mathrm{~kg} \mathrm{ha}^{-1}$, emissions from no-till corn were $7.9 \mathrm{~kg} \mathrm{~N}_{2} \mathrm{O}-\mathrm{N} \mathrm{ha}^{-1} \mathrm{y}^{-1}$ (Parkin and Kaspar, 2006), considerably higher than our mean fluxes; however, corn in these systems received roughly $1.5 \times$ the precipitation and twice the amount of applied fertilizer in a different form compared to our study. Liebig et al. (2005) reviewed gas fluxes from a number of studies throughout the northern Great Plains and found $\mathrm{N}_{2} \mathrm{O}$ emissions ranged from 0.4 to $1.6 \mathrm{~kg} \mathrm{ha}^{-1} \mathrm{y}^{-1}\left(\mathrm{~N}_{2} \mathrm{O}-\mathrm{N}\right)$ in dryland, no-till wheat cropping systems and $6.8-9.0 \mathrm{~kg} \mathrm{ha}^{-1} \mathrm{y}^{-1}$ in irrigated, tilled corn. $\mathrm{N}_{2} \mathrm{O}$ fluxes from our no-till corn plots are at the lower end of the reported range and appear to reflect the combined influences of abiotic (temperature, precipitation) and management (tillage, amount and form of $\mathrm{N}$ fertilization) factors. The positioning of our chambers near (within $5 \mathrm{~cm}$ ), but not across the location of banded starter fertilizer, might have caused lower measured fluxes. However, only about $25 \%$ of the annual $\mathrm{N}$ application was banded dry as starter with the majority being broadcast. Peaks of $\mathrm{N}_{2} \mathrm{O}$ at spring thaw and following fertilization were observed in the current study, similar to other researchers (Venterea et al., 2005; Johnson et al., 2010; Liebig et al., 2010). 

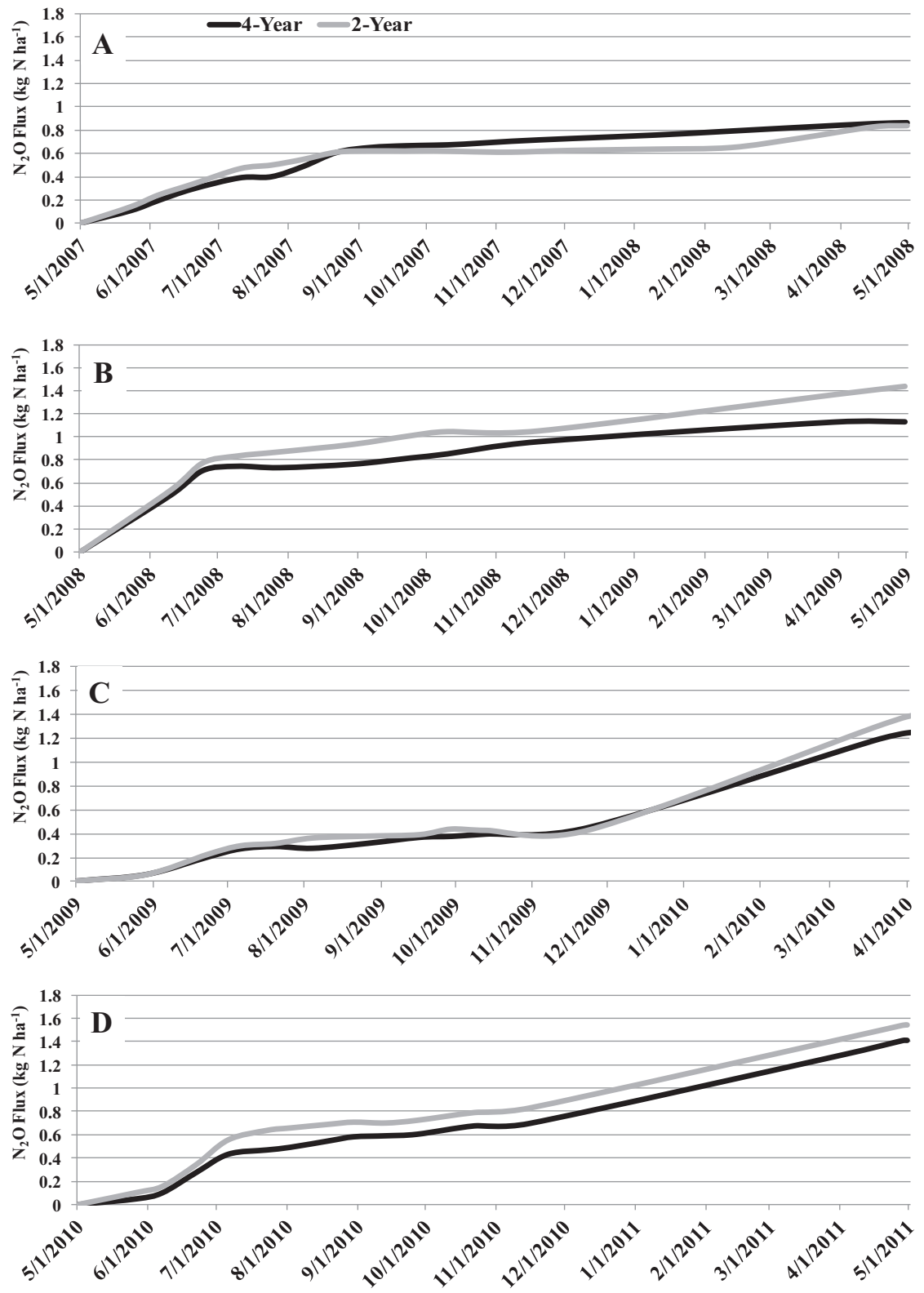

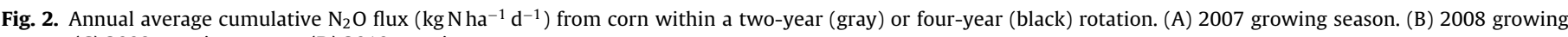
season. (C) 2009 growing season. (D) 2010 growing season.

\subsection{Methane fluxes}

Mean annual fluxes of $\mathrm{CH}_{4}$ over four years from dryland, notill corn in this soil climatic region were $0.9 \mathrm{~kg} \mathrm{ha}^{-1}\left(\mathrm{CH}_{4}-\mathrm{C}\right)$ with no effect of rotational treatment. The identification of corn as a potential source of $\mathrm{CH}_{4}$, rather than a sink, contrasts with other studies that have found either neutral or negative fluxes. Bavin et al. (2009) reported that annual $\mathrm{CH}_{4}$ flux was negligible from two years of a corn-soybean rotation located roughly $330 \mathrm{~km}$ east of our site. Venterea et al. (2005) also reported that an eastern Minnesota corn-soybean rotation was a $\mathrm{CH}_{4}$ sink, regardless of tillage or nitrogen fertilizer form treatments. In the nine-year Michigan study of a no-till corn-soybean-wheat rotation (Robertson et al., 2000 ), the plots were found to be a modest $\mathrm{CH}_{4}$ sink. In a survey of methane fluxes from a variety of dryland small grain cropping systems across a broad geographic area (Liebig et al., 2005), average $\mathrm{CH}_{4}$ fluxes were negative $\left(-1.4 \mathrm{kgCH}_{4}-\mathrm{Cha}^{-1} \mathrm{y}^{-1}\right)$, as were several no-till small-grain cropping systems in central North Dakota (approximately $-1 \mathrm{~kg} \mathrm{CH}_{4}-\mathrm{Cha}^{-1} \mathrm{y}^{-1}$ ) (Liebig et al., 2010). While Johnson et al. (2010) found that corn grown in a 2-year rotation was a sink measuring about $1 \mathrm{kgCH}_{4}-\mathrm{Cha}^{-1} \mathrm{y}^{-1}$; they also found that corn grown in a 4 -year rotation produced $0.4 \mathrm{kgCH}_{4}-\mathrm{Cha}^{-1} \mathrm{y}^{-1}$; a difference that was statistically-significant.

Methane flux measurements are highly temporally variable, even on an annual basis (Johnson et al., 2010; Liebig et al., 2010). In our plots, $\mathrm{CH}_{4}$ fluxes were neutral or negative for 2006 (unpublished, partial year data) and 2007 and then became positive for the period of 2008-2010 which accompanied steadily increasing soil moisture values. The accuracy of our estimates of annual cumulative fluxes is dependent on the frequency of observations (Parkin and Kaspar, 2004; Parkin, 2008). During the winters of 2008, 2009, and 2010, there was heavy snow cover and the chambers were not sampled since digging them out may have created a non-representative measurement site. Since the cumulative gas flux was calculated by linear interpolation between measurements, the measurements bracketing intervals without 

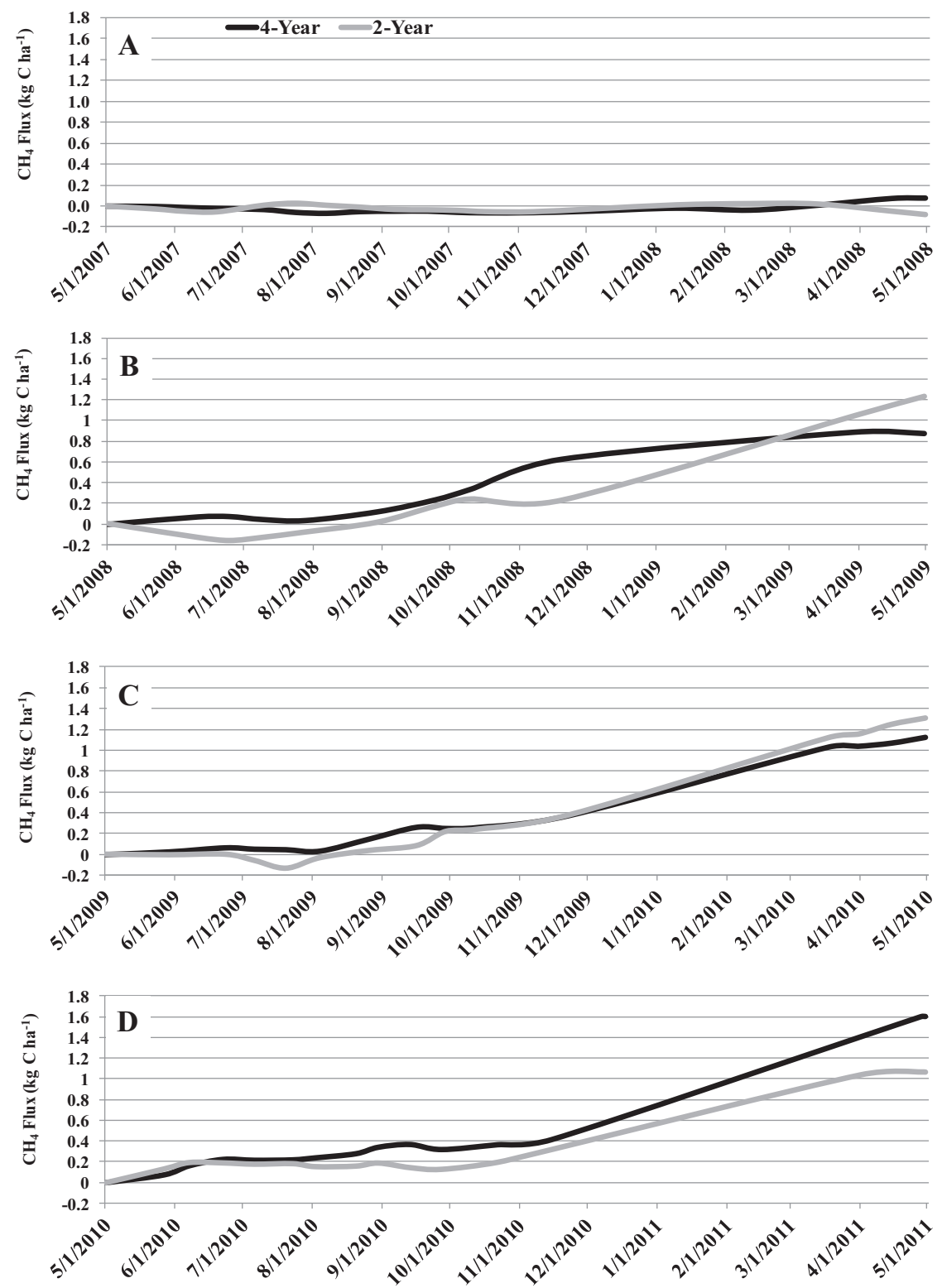

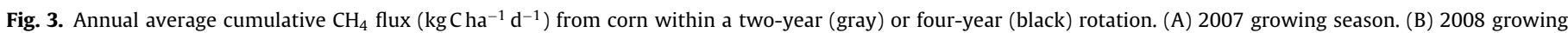
season. (C) 2009 growing season. (D) 2010 growing season.

measurements may have undue influence on the cumulative gas flux. For $\mathrm{CO}_{2}$, fluxes were relatively low immediately before and after winter. However, for $\mathrm{N}_{2} \mathrm{O}$ and $\mathrm{CH}_{4}$, these measurement times often produced the highest values for the year (particularly 2009 and 2010) and therefore the interpolated fluxes during periods of heavy snow cover could be higher than actual values. If $50 \%$ of the winter fluxes were assumed to be overestimated due to this potential artifact, our flux averages for the years 2008-2010 would be around $1 \mathrm{~kg} \mathrm{~N}-\mathrm{N}_{2} \mathrm{Oha}^{-1} \mathrm{y}^{-1}$ and $0.8 \mathrm{~kg} \mathrm{CH}_{4}-\mathrm{Cha}^{-1} \mathrm{y}^{-1}$. On the other hand, it is equally likely that we missed some of the peak $\mathrm{N}_{2} \mathrm{O}$ and $\mathrm{CH}_{4}$ fluxes in 2009 and 2010 when the fields were simply too wet to access.

\subsection{Global warming potential}

Our calculated annual GWP of $572 \mathrm{~kg} \mathrm{CO}_{2}$-eq ha ${ }^{-1}$ for $\mathrm{N}_{2} \mathrm{O}$ emissions from no-till corn closely matches the $560 \mathrm{~kg} \mathrm{CO}_{2}$-eq ha ${ }^{-1}$ in annual $\mathrm{N}_{2} \mathrm{O}$ emissions for a no-till corn-soybean-wheat rotation
(Robertson et al., 2000). Adding $30 \mathrm{~kg} \mathrm{CO}_{2}$-eq ha ${ }^{-1} \mathrm{yr}^{-1}$ for methane makes a total of $602 \mathrm{~kg} \mathrm{CO}_{2}$-eq ha ${ }^{-1} \mathrm{yr}^{-1}$ for our no-till corn, which falls within the range of 0.15 and $1.9 \mathrm{MgCO}_{2}$-eq $\mathrm{ha}^{-1} \mathrm{yr}^{-1}$. reported for non- $\mathrm{CO}_{2} \mathrm{GHG}$ at a Minnesota site (Venterea et al., 2005). However, in our 4-year rotation, soil carbon increased in the top $30 \mathrm{~cm}$ by $596 \mathrm{~kg} \mathrm{Cha}^{-1} \mathrm{yr}^{-1}$, which translates to a GWP of $-2.19 \mathrm{MgCO}_{2}$ eq ha ${ }^{-1} \mathrm{yr}^{-1}$ that would easily offset the GWP of the non- $\mathrm{CO}_{2}$ gas fluxes measured from corn. In contrast, soil carbon in the top $30 \mathrm{~cm}$ of the 2-year rotation decreased by an average of $120 \mathrm{~kg} \mathrm{Cha}^{-1} \mathrm{yr}^{-1}$ which would add $440 \mathrm{~kg} \mathrm{CO}_{2}$-eq ha ${ }^{-1} \mathrm{yr}^{-1}$ to that of the non- $\mathrm{CO}_{2}$ gases to make a net GWP of $1.04 \mathrm{MgCO}_{2}$-eq ha ${ }^{-1} \mathrm{yr}^{-1}$ for corn in the 2-year rotation. Our net annual GWP for corn grown in a 2-year rotation is similar to the $1.14 \mathrm{MgCO}_{2}$-eq ha ${ }^{-1} \mathrm{yr}^{-1}$ net GWP calculated by Robertson et al. (2000) for a three-year rotation under conventional tillage. Robertson et al. (2000) calculated an overall net GWP of $140 \mathrm{~kg} \mathrm{CO}_{2}$-eq ha ${ }^{-1} \mathrm{yr}^{-1}$ for their three-year, no-till rotation compared to our negative GWP for corn grown in a fouryear, no-till rotation, although these authors included carbon from 


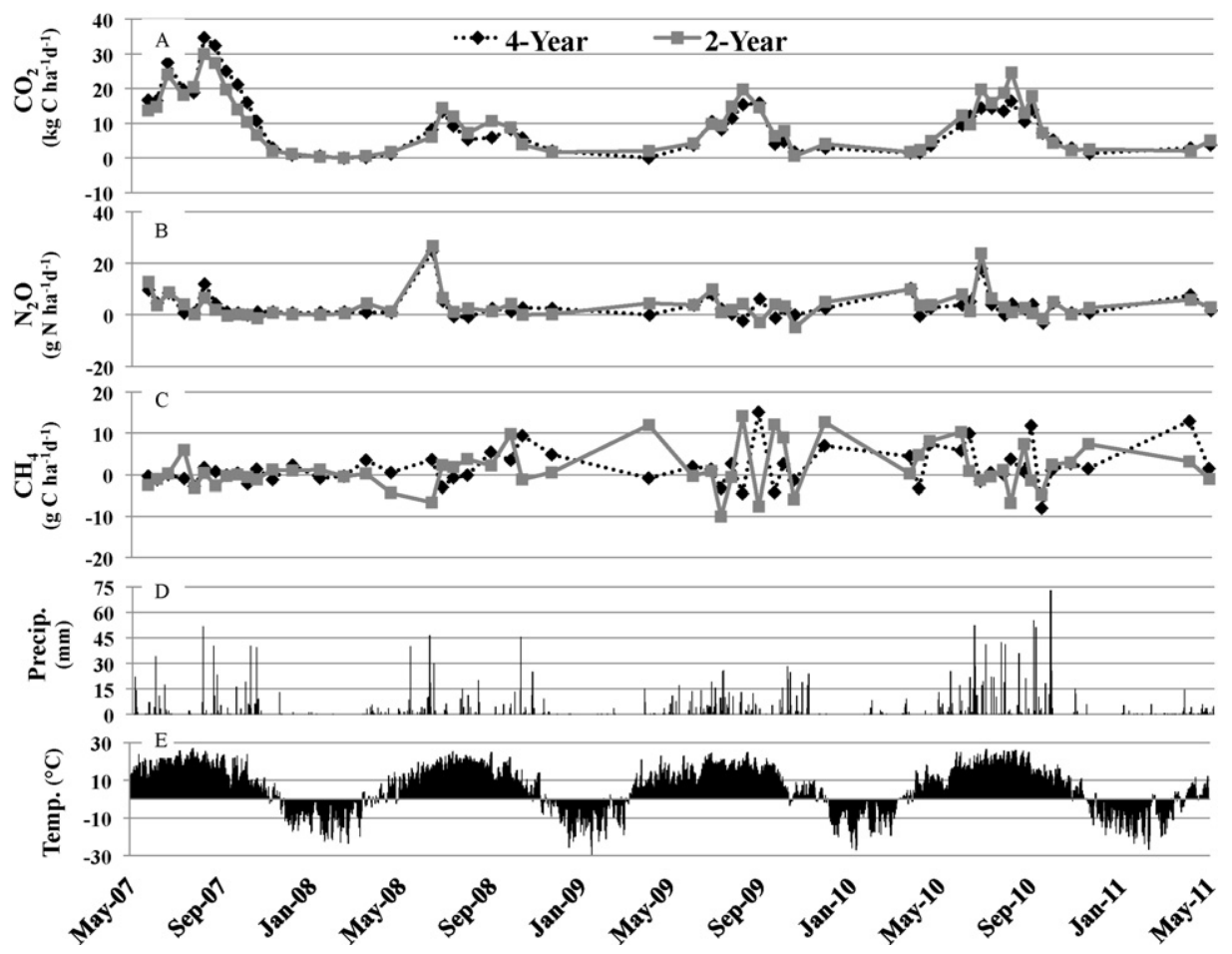

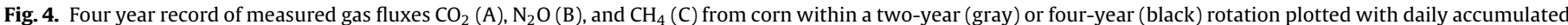
precipitation (D) and average daily temperatures (E).

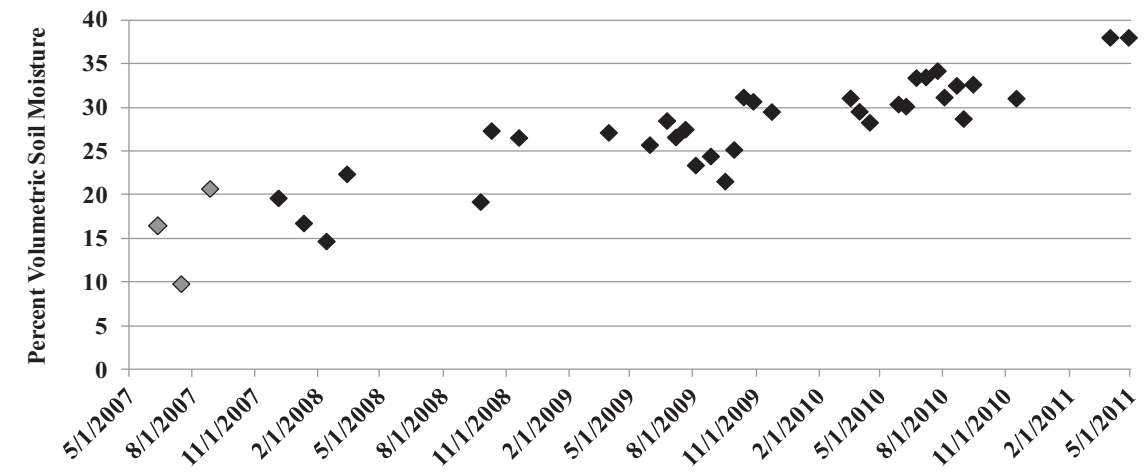

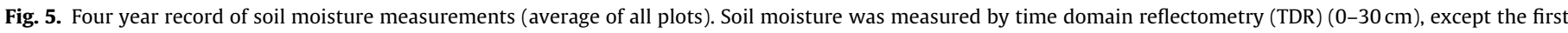

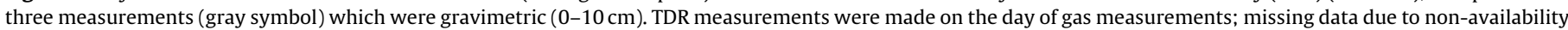
of TDR instrumentation.

liming treatments, fuel, and fertilizer production in addition to changes in soil carbon, which may have been calculated from a smaller depth interval (unclear in publication).

Resolving the cause of the increase in soil $C$ in the four-year rotation was beyond the scope of the current study. Since we found no differences between the rotations in above ground corn biomass, soil $\mathrm{C}$ differences must be attributed to below-ground biomass (not measured) and/or by the inclusion of peas and wheat in the 4-year rotation. Wheat produces a fibrous root system that has been shown to effectively build soil C (Buyanovsky and Wagner, 1987). With respect to the overall GWP for the two rotations, we did not measure GHG fluxes for the other crop phases during this time period. But, it seems unlikely that sufficient $\mathrm{N}_{2} \mathrm{O}$ would be generated to offset the soil carbon accumulated in the 4-year rotation by wheat fertilized with $16 \mathrm{~kg} \mathrm{Nha}^{-1}$ or by unfertilized peas, which have been shown to produce relatively low amounts of $\mathrm{N}_{2} \mathrm{O}$ (Dusenbury et al., 2008; Jeuffroy et al., 2012).

\section{Conclusions}

Despite the relatively large CV in gas fluxes among replicate plots, similar to those reported in other agricultural research plots (Liebig et al., 2005; Johnson et al., 2010; Liebig et al., 2010), we have developed reproducible estimates for soil surface fluxes of $\mathrm{CO}_{2}$ $\mathrm{N}_{2} \mathrm{O}$, and $\mathrm{CH}_{4}$ for dryland corn grown in our soil-climatic region under no-till using broadcast ammonium nitrate. Since there were no treatment effects, these estimates are based on measurements from 16 chambers at 15 time points (average number of annual sampling occasions) replicated over four years. Fluxes for $\mathrm{CO}_{2}$ and $\mathrm{N}_{2} \mathrm{O}$ were lower than measured for many other systems, while $\mathrm{CH}_{4}$ fluxes were higher and highlight the potential for dryland corn to be a $\mathrm{CH}_{4}$ source, rather than a sink, when soils trend to higher moisture levels. Accrual of soil carbon in the diversified 4-year rotation may mitigate the potential warming due to production of GHG from corn in comparison to the standard 2-year rotation. Direct measurements of GHG emissions from dominant human activities 
will improve predictive modeling of climate change and promote identification of specific mitigation targets (Montzka et al., 2011). Data from the current study and other GRACEnet locations support this goal by quantifying gas emissions from dominant agricultural systems under regionally-specific soil-climatic conditions.

\section{Acknowledgements}

We acknowledge the technical support of Amy Christie, Ann Qualm, Kurt Dagel, Chris Nelson, Sharon Nichols and a number of undergraduate students during the course of this study. This publication is based upon work supported by the Agricultural Research Service under the ARS GRACEnet Project.

\section{References}

Adams, R.M., McCarl, B.A., Mearns, L.O., 2003. The effects of spatial scale of climate scenarios on economic assessments: an example from U.S. agriculture. Climatic Change 60, 131-148.

Bavin, T.K., Griffis, T.J., Baker, J.M., Venterea, R.T., 2009. Impact of reduced tillage and cover cropping on the greenhouse gas budget of a maize/soybean rotation ecosystem. Agric. Ecosyst. Environ. 134, 234-242.

Bryce, S., J.M., O., Pater, D.E., Ulmer, M., Schaar, J., Freeouf, J., Johnson, R., Kuck, P., Azevedo, S.H., 1998. Ecoregions of North Dakota and South Dakota. Northern Prairie Wildlife Research Center Online, Version 30NOV1998, Jamestown. http://www.npwrc.usgs.gov/resource/habitat/ndsdeco/index.htm (accessed 08.12.12).

Bullock, D.G., 1992. Crop rotation. Crit. Rev. Plant Sci. 11, 309-326.

Buyanovsky, G.A., Wagner, G.H., 1987. Carbon transfer in winter wheat (Triticum aestivium) ecosystem. Biol. Fert. Soils 5, 76-82.

Carpenter-Boggs, L., Pikul, J.L., Vigil, M.F., Riedell, W.E., 2000. Soil nitrogen mineralization influenced by crop rotation and nitrogen fertilization. Soil Sci. Soc. Am. J. 64, 2038-2045.

Dusenbury, M.P., Engel, R.E., Miller, P.R., Lemke, R.L., Wallander, R., 2008. Nitrous oxide emissions from a northern Great Plains soil as influenced by nitrogen management and cropping systems. J. Environ. Qual. 37, 542-550.

FAO, 2002. World Agriculture: Towards 2015/2030. Food and Agriculture Organization of the United Nations, Rome.

GGWP, 2010. Agriculture's Role in Greenhouse Gas Emissions and Capture. Greenhouse Gas Working Group. ASA, CSSA, SSSA, Madison.

Hutchinson, G.L., Mosier, A.R., 1981. Improved soil cover method for field measurements of nitrous oxide fluxes. Soil Sci. Soc. Am. J. 45, 311-316.

IPCC, 2007a. Climate Change 2007: Synthesis Report. Contribution of Working Groups III and III to the Fourth Assessment Report of the Intergovernmental Panel on Climate Change. IPCC, Geneva.

IPCC, 2007b. Contribution of Working Group I to the Fourth Assessment Report of the Intergovernmental Panel on Climate Change 2007. Cambridge University Press, Cambridge, United Kingdom.

Jawson, M.D., Shafer, S.R., Franzluebbers, A.J., Parkin, T.B., Follett, R.F., 2005. GRACEnet, greenhouse gas reduction through agricultural carbon enhancement network. Soil Till. Res. 83, 167-172.
Jeuffroy, M.H., Baranger, E., Carrouee, B., de Chezelles, E., Gosme, M., Henault, C., Schneider, A., Cellier, P., 2012. Nitrous oxide emissions from crop rotations including wheat, rapeseed, and dry pea. Biogeoscience Discuss. 9, 9289-9314.

Johnson, J.M.-F., Archer, D., Barbour, N., 2010. Greenhouse gas emissions from contrasting management scenarios in the northern corn belt. Soil Sci. Soc. Am. J. 74, 396-406.

Kessavalou, A., Doran, J.W., Mosier, A.R., Drijber, R.A., 1998. Greenhouse gas fluxes following tillage and wetting in a wheat-fallow cropping system. J. Environ. Qual. 27, 1105-1116.

Liebig, M.A., Morgan, J.A., Reeder, J.D., Ellert, B.H., Gollany, H.T., Schuman, G.E., 2005. Greenhouse gas contributions and mitigation potential of agricultural practices in northwestern USA and western Canada. Soil Till. Res. 83, 25-52.

Liebig, M.A., Tanaka, D.L., Gross, J.R., 2010. Fallow effects on soil carbon and greenhouse gas flux in central North Dakota. Soil Sci. Soc. Am. J. 74, 358-365.

Lubowski, R.N., Vesterby, M., Bucholtz, S., Baez, A., Roberts, M.J., 2006. Major Uses of Land in the United States, 2002. Economic Informatio n Bulletin No. (EIB-14). USDA-Economic Research Service, Washington, DC, p. 54.

Montzka, S.A., Dlugokencky, E.J., Butler, J.H., 2011. Non- $\mathrm{CO}_{2}$ greenhouse gases and climate change. Nature 476, 43-50.

NASS, 2012. U.S Corn Acreage by Year. U.S. Department of Agriculture, National Agricultural Statistics Service, Washington, D.C.

Nelson, D.W., Sommers, L.E., 1996. Total carbon, organic carbon, and organic matter. In: Sparks, D.L., Page, A.L., Helmke, P.A., Loeppert, R.H., Soltanpour, P.N., Tabatabai, M.A., Johnston, C.T., Sumner, M.E. (Eds.), Methods of Soil Analysis, Part 3: Chemical Methods. Soil Science Society of America, Madison, pp. 961-1010.

NRCS, 2006. Land Resource Regions and Major Land Resource Areas of the United States, the Caribbean and the Pacific Basin. U.S. Department of Agriculture Handbook 296, U.S. Department of Agriculture, Washington, DC.

Omonode, R.A., Smith, D.R., Gal, A., Vyn, T.J., 2011. Soil nitrous oxide emissions in corn following three decades of tillage and rotation treatments. Soil Sci. Soc. Am. J. 75, 152-163.

Parkin, T.B., 2008. Effects of sampling frequency on estimates of cumulative nitrous oxide emissions. J. Environ. Qual. 37, 1390-1395.

Parkin, T.B., Kaspar, T.C., 2004. Temporal variability of soil carbon dioxide flux: effect of sampling frequency on cumulative carbon estimation. Soil Sci. Soc. Am. J. 68, 1234-1341.

Parkin, T.B., Kaspar, T.C., 2006. Nitrous oxide emissions from corn-soybean systems in the Midwest. J. Environ. Qual. 35, 1496-1506.

Parkin, T.B., Venterea, R.T., 2010. Chamber-Based Trace Gas Flux Measurements. In: Follett, R.F. (Ed.), Sampling Protocols. , pp. 3.1-3.39, Available at: http://www.ars.usda.gov/research/GRACEnet (accessed 08.12.12).

Pikul, J.L., Osborne, S., Ellsbury, M., Riedell, W., 2007. Particulate organic matter and water-stable aggregation of soil under contrasting management. Soil Sci. Soc. Am. J. 71, 766-776.

Riedell, W.E., Pikul, J.L., Jaradat, A.A., Schumacher, T.E., 2009. Crop rotation and nitrogen input effects on soil fertility, maize mineral nutrition, yield, and seed composition. Agron. J. 101, 870-879.

Robertson, G.P., Paul, E.A., Harwood, R.R., 2000. Greenhouse gases in intensive agriculture: contributions of individual gases to the radiative forcing of the atmosphere. Science 289, 1922-1925.

USGS, http://tapestry.usgs.gov/physiogr/physio.html (accessed 08.12.12).

Venterea, R.T., Burger, M., Spokas, K.A., 2005. Nitrogen oxide and methane emissions under varying tillage and fertilizer management. J. Environ. Qual. 34, 1467-1477. 